\title{
THE FUNCTION OF LAW IN A DEMOCRATIC SOCIETY*
}

\author{
Charrees E. Clark
}

W HEN, not long since, I was asked to try to explain the function-if any-of law in a democratic society to a conference of scholars and writers interested in demonstrating American solidarity, I hesitated long before undertaking the task. Not that I lacked convictions, for a considerable battling in the fields of law and education had yielded me some firmly held views. I did fear, however, that these views were, for most students, so commonplace as hardly to justify restatement. That law is but the tool, not the driving force, of the great society, that it must remain ever servant, never master, is a statement hardly likely to startle modern ears. But I recalled how repeatedly I had found myself brought up short with renewed evidences that however general may be the lip service paid these views, yet there was deeply ingrained in man the feeling that law embodies something outside and beyond one's self-something partaking of the divine-to which he must make obeisance. And so ultimately I undertook the task. For it has seemed to me that, whatever might be the temporary uses of such a feeling among those with whom a policeman's club is more authoritative than are philosophical ideals, from a longer point of view it was not only false and misleading, but actually inimical to the democratic way of life. If the people are not in command of their own government, but are actually subordinate to some yet more remote sovereign who upholds and justifies unsanitary conditions, poor housing, long hours of labor, and general defiance of social welfare legislation as a freedom required by some vague constitutional command or higher law of nature, then we are nearer either anarchy or the rule of the autocratic few than we are democracy. And though some of the excrescences of the higher law doctrine have been pruned

\footnotetext{
* The substance of this paper was presented as an address before the Conference on Science, Philosophy and Religion in their Relation to the Democratic Way of Life, at Columbia University in New York City, on September 9, r94I. As originally given it appears in Science, Philosophy and Religion, Second Symposium (1942), published by the conference.
}

$\dagger$ Judge, United States Circuit Court of Appeals for the Second Circuit. 
away in modern jurisprudence, yet enough remains alive to give us pause, indeed, to require some thoughtful consideration as to the role of law in a modern democracy.

There is now, of course, much talk of "the newer jurisprudence." To a bar association protagonist this is likely to represent some New Deal aberration of constitutional law, temporarily misleading our courts; to older juristic scholars it may mean the wild confusion of those so-called legal realists who just do not know what real juridical thought is; while to others of us it may not seem so much new as a return to first principles. However that may be, one quality of modern legal thinking is striking compared to. older views. That is its frankness. Whereas formerly jurists and scholars spoke and seemingly thought of the law as a majestic symbol of ultimate authority, sacrosanct in its majesty and benignity, now all tend to dissect judicial rulings as does the anatomist the human body. When they find that what has been announced as the voice of the sovereign will is but a distillation of the economic beliefs and environmental conclusions of its protagonists, they do not hesitate to say so. So far in fact has this trend gone that the legal realists have acquired the nameor frame - of the "gastronomical school of jurisprudence," since they are supposed to attribute judicial decision primarily to what the judge had for breakfast. ${ }^{2}$

In one famous roll call of American legal realists, I had the honor, possibly dubious, of being singled out by name for omission. ${ }^{3}$ These gentlemen, when named together, appear to represent so many differing points of view that one can hardly attach himself to all of them at one time. But

I Professor Kessler even says "today a renaissance of natural law is under way" and "positivism is on retreat." Theoretic Bases of Law, 9 Univ. Chi. L. Rev. 98, 104 (194I). But his citations, as to Haines, The Revival of Natural Law Concepts (I930), indicate a view directed over a century or more, rather than over developments of the last decade, though he does add Fuller, The Law in Quest of Itself (I940). How far the latter may represent a modern trend may perhaps be doubted. See McDougal, Fuller v. The American Legal Realists: An Intervention, 50 Yale L. J. 827 (I94I); also references in notes 2 and 3 infra. With reference to constitutional law - the immediate subject matter of this paper-the present view of our highest court is undoubtedly pragmatic and positivistic.

2 For a bibliography of the realists, see Garlan, Legal Realism and Justice (194r); also compare McDougal, op. cit. supra note $\mathrm{r}$; Fuller, op. cit. supra note $\mathbf{x}$; and other references infra.

3 By Dean Pound-whether as pat or kick, I still am not sure-when asked for a bill of particulars as to his The Call for a Realist Jurisprudence, 44 Harv. L. Rev. 697 (r93I); see Llewellyn, Some Realism about Realism-Responding to Dean Pound, 44 Harv. L. Rev. I222, I226, I227 (I93I); cf. Llewellyn, review of Pound, Contemporary Juristic Theory, 26 A.B.A.J. 876, 878 (r940); Clark, The Higher Learning in a Democracy, 47 Internat'l J. of Ethics $3^{\text {I } 7}$ (1937). 
they do have one thing in common, which is, I believe, undoubtedly the most healthy thing in the law today. That is their attempt to face fairly and honestly, without cant or preconceived conclusions, what is actually happening in the courts, in legislatures, and in the executive departments today. ${ }^{4}$ This is truly a cleansing breeze blowing away many of the inhibitions which in the past have hampered or prevented democratic progress.

As an example of the type of thing from which we are getting away there may be cited Harrington's aphorism (by him ascribed to Aristotle and Livy) of an "empire" or a "government" "of laws and not of men,"s so long held up to us as perhaps the ultimate in political desirability. ${ }^{6}$ We did not perceive as we should that in final essence men both made and applied the laws, even those for which was claimed a philosophical basis in doctrines of the seventeenth and eighteenth century thinkers, if not of Magna Carta. ${ }^{7}$ But a measure of our progress in freedom of the mind is shown by our straightforward legal approach to present-day exploitation of the masses, as contrasted with the constitutional theory of a half century ago which sustained such exploitation by an expansion-now universally considered unwarranted-of the procedural concept of due process of law. I think we must regard that period, the period of the last quarter of the last century when the natural resources of the country were used for the advantage of the few, as perhaps the sorriest period of our history, sorriest because government found itself without power, as well as without will, to curb such excesses. ${ }^{8}$ We ought to make a solemn covenant with ourselves that never again will the concepts of our law be allowed to become so divorced from reality as to permit such a condition of affairs to exist not merely untrammelled, but with well-nigh complete judicial support.

4 Cf. Frank, Mr. Justice Holmes and Non-Euclidian Legal Thinking, r7 Cornell L. Q. 568, 586 (1932), as quoted by McDougal, op. cit. supra note r, at 835; Frank, If Men Were Angels c. 6, Holmes" "Bad Man" Starts Something, and App. 5, Some Criticisms of the So-called "Realists" (1942).

5 Harrington, Oceana, published in 1656 , the Morley ed. of 1887 reprinted in Coker, Readings in Political Philosophy 500, 50r, 5 II, 520 (1938).

${ }^{6}$ Cf. Mass. Const. (I780) Bill of Rights, art. 30; Marshall, J., in Marbury v. Madison, I Cranch (U.S.) 137, $_{363}$ (1803); Harlan, J., in Sparf v. United States, 156 U.S. 51, 103 (I895).

7 Cf. Llewellyn, On Reading and Using the Newer Jurisprudence, $4 \circ \mathrm{Col}$. L. Rev. 58r, 583 (r940), 26 A.B.A.J. 300, 30I (1940); Bingham, in My Philosophy of Law 7 (194I).

${ }^{8}$ As described, for example, in Beard and Beard, The Rise of American Civilization c. 2o, The Triumph of Business Enterprise, and c. 25, The Gilded Age (r939); Josephson, The Robber Barons (r934); or Josephson, The Politicos (r938). 
It is interesting to trace the changes in our legal thinking, particularly in the field of public law, which have taken place since that time. One may venture the thought that a somewhat similar gain in frankness and directness may be found elsewhere, as, for example, in literature; but these are probably waters in which a lawyer should not venture. At any rate, it does appear to be a rather general development, not limited to law alone. It follows the growing political awareness of the masses, stimulated by popular education and led by public figures able to voice these aspirations in vigorous language. A Theodore Roosevelt, for example, may have lacked some qualities of philosophical genius, but he possessed a magnificent vocabulary of reform. Thanks to him and to others, ideas formerly heterodox became common thoughts of the market place.

Confining our survey to the law, it is interesting to note the prominent part played in the movement by the law schools. The intellectual ferment sorecently characteristic of legal thinking has largely centered in the schools, particularly during the late 'twenties and early'thirties and just before the break in judicial absolutism finally came. Law teaching as a profession is a recent development in this country; it has borne fruit rapidly. Not until Langdell and Eliot at Harvard brought in the full-time teacher to apply their new thought-producing process of the case method was the law lecturer more than a lawyer or a judge engaged in a little part-time activity. But that was entirely changed with the growth of a fairly unified group of scholars spending their lives in the criticism of legal opinions and the training of youthful minds themselves to make such criticism. First the law professor explored the precedents of the past, and this, too, had its devastating effect. Thus, many a cherished notion of supposed historical antiquity, employed as the foundation stone of a modern limiting decision, was shown to have but a factitious existence in some lawyer's mind rather than in age-old judicial action. Thereafter and in the early days of this century when the case method had thoroughly won its way, the law teachers turned their attention to the condition of the masses, the effect of economic interests upon the law, and the sociological aspects of the law. After sociological jurisprudence and analytical jurisprudence came in turn the modern realism, which was either the ultimate defilement of the temple or the law's final attainment of maturity and its exorcise of totemism, depending upon the point of view.9

9 I have attempted to describe this before, as in Legal Education in Modern Society, to Tulane L. Rev. I (I935), or The Higher Learning in a Democracy, 47 Internat'l J. of Ethics 3I7 (r937). Cf. Douglas and Clark, Law and Legal Institutions, 2 Recent Social Trends in the United States, Report of the President's Research Committee on Social Trends r430-88 (r933). 
Meanwhile, of course, this view was reflected in judicial opinion, as in the great dissents of Justices Holmes and Brandeis and of the present Chief Justice. The succinct statement of this attitude can be found in Justice Holmes' famous dissent some twenty-five years ago: "The common law is not a brooding omnipresence in the sky, but the articulate voice of some sovereign or quasi-sovereign that can be identified."10 Only lately the Supreme Court, in a decision to lawyers the most important of years, the Tompkins case, ${ }^{\text {II }}$ has accepted this doctrine in its fullest meaning: unless the law can be found as the expression of the will of some sovereign, either a state or the nation, it is, so the Court holds, not to be accepted as law at all. The particular aspect of the problem then decided was that there was not even a common law throughout the United States, but only the varying law of the particular states in those realms which the national law of the Federal Government did not touch. That the modern jurisprudence of the Supreme Court has been so largely influenced by the law schools, that, indeed, a goodly number of the Court's present members are recruits, mediate or immediate, from the law teaching profession, is an effective and a practical tribute to the vigor and vitality both of the law schools and of the doctrines they have preached..$^{12}$

But, it may be asked, considering what is now the accepted view of the highest court of the land, to which all inferior courts must conform, why is it not whipping a dead horse once again to restate and to reemphasize these theories? In turn, we might well ask why, in the light of this development so much in line with scholarly thought and lay desires, with present-day political views and social needs, do we find so much direct resistance to these ideas? For resistance there is, and we are naive, indeed, if we do not recognize that fact. Last June, the president of one of our largest industrial corporations-himself undoubtedly honest and sincere in his beliefs-took the occasion of a commencement speech to express his fear of the views of "Reds, pinks, parlor pinks, Nazis and Fascists, and all the other members of that strange crew which today claim the right to destroy our institutions under the protection of the very constitution

${ }^{10}$ Southern Pacific Co. v. Jensen, 244 U.S. 205, 222 (I917).

II Erie R. Co. v. Tompkins, 304 U.S. 64 (1938). The voluminous literature about this case still pours forth. A late authoritative statement is in this journal, Developments in the Doctrine of Erie Railroad Co. v. Tompkins, 9 Univ. Chi. L. Rev. x13, 308 (194I-42).

${ }^{2}$ An interesting example of how law teaching has shaped Supreme Court adjudication has just appeared. Messrs. Taylor and Willis, as students of Professor Frankfurter, wrote the valuable article, The Power of Federal Courts to Enjoin Proceedings in States Courts, 42 Yale L. J. I 169 (I933), which has now supplied the foundation for the decision of Mr. Justice Frankfurter in Toucey v. New York Life Ins. Co., 3I4 U.S. II8 (I94I). 
which they themselves despise," in contrast to the yet recent past where "there was still ingrained in us the Anglo-Saxon's deep respect for law founded upon a constitution and as interpreted by our courts with an almost predictable consistency for more than roo years." "x3 Had I not seen similar thoughts expressed in more delicate language by skilled lawyers of our time, ${ }^{x_{4}} \mathrm{I}$ should have expected all lawyers to smile at the almost predictable consistency of decision which the gentleman thought a possession just lost. I wonder if he would recall; for example, the decision of I895 invalidating the income tax, contrary to previous precedents and aided by the shift of vote of a single justice..$^{x 5}$ If there has been any change, it is in the direction of gain in predictability of decision in private law at least, as research into the past and facilities for understanding and stating the law of the present have been developed. In the law of property-in such erudite subjects as future interests, for example-in commercial law with the development of uniform legislation in the various states, in many aspects of corporate law and bankruptcy reorganization, I think there has been undoubtedly a gain in certainty, even though we now come to realize that law cannot stand still, that in certain aspects it must remain ever flexible and even changeable. Moreover, there are now definite and extensive movements for the precise formulation of these rules of private law, of which the National Conference of Commissioners on Uniform State Laws and the American Law Institute are outstanding examples.

But I suppose the speaker had mainly in mind problems of public law.

${ }_{3}$ Brinley, Universities as Leaders, 4 Yale Alumni Mag. Io (July II, I94x).

14 Perhaps an even more striking illustration may be found in the reaction in high legal circles to this very address. Thinking it appropriately dull and restrained, I sent it to the official journal of the organized bar, the American Bar Association Journal. To my utter surprise the editors started to demur, expressing the need of a reply in the event of publication and so on; and, after some three months of cogitation and debate by the full editorial board and upon vote by a minority thereof, they ultimately rejected it on the ostensible ground that it was not in the Journal's field, notwithstanding a rather general preoccupation of the Journal with the American way of life, at least as conceived by the lawyers. I should have been less surprised had I then known of the like fate accorded Professor Davis' article, Dean Pound and Administrative Law, now published in 42 Col. L. Rev. 89 (1942), which, in view of its nature and content, would seem to be a "must" for a scholarly journal under the circumstances.

${ }^{15}$ Pollock v. Farmers' Loan \& Trust Co., I58 U.S. 6or (I895), reversing in part 157 U.S. 429 (1895). Speculation as to the identity of the variable justice has long continued; for various candidates, see 2 Warren, The Supreme Court in United States History 700 (rev. ed. 1928); Putney, Five to Four Decisions, 24 Yale L. J. 460, 464 (I9r5); Hackett, The Income Tax Cases-A Correction, 24 Yale L. J. 66r (r915); Corwin, The Twilight of the Supreme Court 210 (1937); Corwin, Court over Constitution I94-20I (1938); Nevins, Grover Cleveland app. 2 (1934). 
Here, too, I suggest that there is greater consistency at the moment than at any time since that early period, prior to the Civil War, of judicial restraint in invalidating legislation. If we think back a few years ago we can recall the uncertainty that existed as to how far the courts would really venture to go in striking down statutes. We are told by historians that the number of actual occasions when the highest court thus acted were few; even so, the possibility that it might act caused counsel to bring case after case to it in pursuit of this hope. True, every crisis, foreign or domestic, caused retreat from those constitutional extremes; but the shifts in doctrine were far from conducive to a general belief in predictable consistency.

But the statement quoted, however invalid in point of fact, does clearly reveal the speaker's belief that the present trend has been unfortunate. Far from being an isolated phenomenon, this same attitude is continuously reflected in the expressed views of business leaders and in the conservative press, as well as in the steady trend of litigation, mostly unsuccessful, still brought to our courts. ${ }^{16}$ Thus, one cannot hear daily the various appeals in labor cases without realizing that the principles adopted by our legislative bodies, including the Congress of the United States, requiring union recognition even to the extent of negotiation with non-employees of a plant are not yet fully accepted by a large portion of the industrial public. One case follows another in the same pattern wherein negotiation with employees is accepted, but the interference of outsiders, so called, is bitterly resented, even though these are the chosen representatives of the employees. ${ }^{17}$

Moreover, still widespread is the view of the law which conceives of its only function as that of forbidding or negating action, without apparent realization that it can and must be dynamic and constructive. In no place is this more true than in a democracy, where the law must be employed to foster and safeguard that equality of opportunity which is the essence of the democratic way of life. To such end, as we have found, have we had to use the machinery of the law to compel recognition of the principle of unionization of labor. It is quite clear that in no other way would it have received effective recognition..$^{18}$ Many other examples of

${ }^{16}$ Compare the incident described in note 14 supra.

17 Many instances may be adduced; perhaps as concise a statement as any is that of Minton, J., in the recent case of Rapid Roller Co. v. NLRB, 3 C.C.H. Lab. Law Serv. If 6o,gor (C.C.A. 7 th $\mathrm{I942}$ ). It is to be expected that this attitude will lessen and very likely has lessened even since the outbreak of war.

${ }^{28}$ Brooks, When Labor Organizes 277 et seq. (1937); cf. Collective Bargaining under the Wagner Act, 5 Law \& Contemp. Prob. I75-330 (1938). 
similar kind may be cited. Thus, the principles of truth and fair dealing in security transactions, the regulation of wages and hours, the adjustment of prices to prevent runaway inflation-all these are but types of well-known problems which the statutory law must and can advance towards solution.

Is it not true, therefore, that we allow ourselves a good deal of cant and of false pride about our law, and that we thus assume attitudes which force upon us inhibitions unworthy of a free people, but which do not fool the dictator governments in the slightest? For while the dictators' treatment of law seems unduly cynical, they are completely convinced that we are in fact just as cynical and that actually our legal restraints are but the means whereby a capitalistic organization preserves power in the hands of the few. I think we would do much better to face the issue squarely and to recognize that the function of law in a democracy is not greatly different from its function in an autocracy or a dictatorship. Of course, the content of law is as different as are the diverse social ideals of the two systems. ${ }^{x 9}$ But in each case it is the objective of law to carry out the adjustment of rights between man and man and between man and the sovereign according to the ideological purposes of the state. We not only cannot, we should not, expect law to rise above its source in the sovereign will; and if our principle of government is that on ultimate analysis that sovereign will is the will of the majority, we ought to be honest enough with ourselves to say that we shall seek that will as directly as possible and that we will obey its commands when we discover what they are. I think that this is not only an essential to our future democratic way of life, but a principle whose recognition will free us from inhibiting restrictions which do operate against democracy and in favor of autocracy. I suggest that the history of our constitutional law has been one of an attempt to get away from such inhibitions, and that as a general rule the further we have gotten away from them and the more we have trusted the legislature as representative of the people, the nearer we have approached the democratic ideal. ${ }^{20}$

Now it is to be said that in general our inheritance of the English law has served us well so far as private rights are concerned. The adjustment of differences between man and man resting on a solid core of Anglo-

${ }^{29}$ This is completely, even dismayingly, demonstrated by Roper and Leiser, Skeleton of Justice (I94I), a book which all lawyers should read for its portrayal of the depths to which law has been degraded in Nazi Germany.

${ }^{20}$ The various departures from and returns to popular control have been often traced; for a recent and complete treatment, see Jackson, The Struggle for Judicial Supremacy (I94I). 
Saxon law has given substantial satisfaction-is, indeed, one of our sources of pride. That there are difficulties-that, for example', the legal profession is not well organized to render adequate legal service to the lower middle income groups or even to care for its own less prosperous contingent ${ }^{2 x}-i$, of course, true and obvious. But the fundamentals are there, strong and serviceable.

It is with the field of public law that our chief concern arises. There a rapidly expanding economy has spread far outside the rather narrow channels of activity envisaged by the constitutional fathers. In this quarter we have accepted an inflexibility of doctrine which is really foreign to the spirit of Anglo-Saxon law and from which our most direct ancestors, the English, have been able largely to free themselves..$^{22}$ It is true that the whole trend of the times is toward greater flexibility. But can it be achieved by the sole process of judicial attrition with sufficient speed to preserve democracy in a world opposed to its ideas and ideals? Of course, we must expect some delays in the operation of the democratic process, and we must yield to dictatorships the palm for direct and speedy action even in peace and most certainly in war. Even so, we have tolerated certain clogs on that process which appear not merely unnecessary, but also unwise, in a truly democratic organization. There is a gap between the people and their representatives which we do not bridge, and which serves admirably to promote irresponsibility and disunity.

This appears notably in the recurring phenomena of our national elections. Once every four years we indulge in what we love to term a popular referendum; and after great excitement and large expenditures over a period of five or six months, or more, we register our choice at the polls. Yet by the time the successful candidate has taken his seat, world conditions, as well as local views, may have entirely changed, and we cannot

${ }^{2 x}$ There has been increasing interest of the bar in this matter. Among recent references, see Llewellyn, The Problem of Undone Legal Service, 26 A.B.A.J. 38 (I940); The "Unauthorized Practice of Law" Controversy, 5 Law \& Contemp. Prob. I-I74 (I938); Special Committee of the American Bar Association on the Economic Condition of the Bar, The Economics of the Legal Profession (1938); Clark and Corstvet, The Lawyer and the Public: An A.A.L.S. Survey, 47 Yale L. J. 1272 (1938); Law and Lawyers in the Modern World, 15 U. of Cin. L. Rev. I27, x57-90, 228-44 (x94I); Symposium, I6 Tenn. L. Rev. 64I-73I (I94I). [For a recent appraisal of one effort to meet these problems, see Abrahams, The Neighborhood Law Office Experiment, 9 Univ. Chi. L. Rev. 406 (x942).-Ed.]

22 "The decision is premature whether you, and those who agree with you, have been right in trying to shackle the free will of a free people by judicial control, or whether we have been right in trusting the free will and a free people to work out their own salvation." Address by the Earl of Birkenhead (Sir Frederick E. Smith, former Conservative Lord Chancellor) before the American Bar Association, Aug. 29, 1923, Developments of the British Constitution in the Last Fifty Years, 9 A.B.A.J. 578, 581 (1923). 
tell with any degree of assurance how far the executive still represents the popular will. We eagerly scan the ad hoc results of private and profitmaking polls, but naturally find them unsatisfactory except for temporary argumentative uses.

Again it is not considered strange that the responsible heads of the important legislative committees are those who have achieved their posts through seniority and who are outspokenly opposed to the executive program. No unity of action in social advance or even in defense, except in time of crisis, can be achieved by such a process wherein the various parts move in opposition to each other. Indeed, it is a tribute to the genius of our people that when waked to a crisis they can advance to a desired goal in spite of our formal difficulties of organization. Even though the country is large and heterogeneous, the question should be seriously considered whether a true parliamentary system, where the executive must be always responsible to the electorate and at least the legislative heads must be in step with the executive, cannot be achieved. I do not believe the obstacles are insurmountable. ${ }^{23}$ After some centuries of experimentation, England seems to have achieved such a system; and while it does not always act with expedition, as the years before the present war show, yet it does make possible the welding together of classes there in a way which we may well strive to emulate. When Mr. Churchill met Mr. Roosevelt in their recent conferences, he could properly feel that he represented the views of the English Government at the time, and that their confidence in him, until and unless an adverse vote showed the contrary, was a continuing thing. Mr. Roosevelt, however, could say only that on a certain day in November, I940, he appeared to enjoy a like confidence of the American people, and that no further real test of the matter can be had until a day in November, I944, which may, of course, be too late for all democracies. The matter is too important for brief consideration here but should engage the serious attention of political thinkers.

But one may protest that this is to make Demos wholly king. Actually this is far from the case. Of course the interaction of executive and legislature, with the executive taking natural leadership in statutory reform, brings its own checks, which operate for all to see under the English sys-

${ }_{23}$ The mechanics of a general election could be made brief and effective with the mechanical aids which could be easily adopted. Perhaps, of course, the chief necessity would be to develop an effective and always available opposition under a definite leadership. Cf. Brogan, Politics and Law in the United States c. 3 (194r); Clark, Supreme-Court or People?, 6 The American Scholar 20I (I937); Schattschneider, Party Government (I942); Hazlitt, More Flexible Constitution Viewed as National Need, N.Y. Times, p. 6E, col. 5 (Feb. 8, I942); Elliott, The Need for Constitutional Reform c. 9 (I935); Herring, Presidential Leadership c. 4 (I940). 
tem. Neither can go to extreme without running the very real danger of forfeiting that confidence of the electorate which is responsible for its continuance in office. But, more than that, it seems clear that, even under a judicial view of self-abnegation, the restraining control of the courts will be extensive. In England the power of interpretation of laws yields no small measure of control, notwithstanding acknowledged parliamentary supremacy. With us that control goes even further, since the courts are ultimately charged with the duty of ironing out the final frictions of a federal system. The question how far state and National governments may go in opposing ways becomes for almost all practical purposes a judicial one. Further, the extreme pressure for judicial control of administrative agencies means that as the latter grow mightily, so do the courts expand to restrain them. ${ }^{24}$ The means of judicial control are certainly adequate; it is perhaps a more pressing question, for which we cannot stop here, whether judicial techniques are likewise adequate.

In addition, it must be recognized that some of our most direct constitutional limitations have been retained and are likely to remain. The changes just referred to do not touch the fundamental form of our government as a federal system, or the cherished civil liberties of the individual protected by the Bill of Rights. These, too, probably cannot remain static in a changing world and should be subject to enlightened reexamination, like all others of our institutions, even though formal revision is not an immediate possibility. As to the first, the federal system, it must be recognized as one of the great compromises of our history, a compromise which has remained anything but static to date. The necessities of direct action have steadily augmented the power of the Federal Government in the past, and we can expect no other course in the future. What is it that gave John Marshall his great and enduring fame except his ability to foresee just this course and to act upon it at a time when that action was most necessary to the building up of a strong Government? It has been suggested that some change in organization of the states is necessary, perhaps the substitution of regional districts. ${ }^{25} I$ think that is the kind of thinking which deserves our most serious attention, and some such development seems likely to gather support as time goes on. But for my part, I should put this as a problem to be considered after, and not before, that of developing political responsibility along parliamentary lines.

24 The passage of a Price Control Act, Jan. 30, I942, carries with it the creation of a new court, an Emergency Court of Appeals, for review of administrative action under the act.

${ }_{25}$ The suggestion was made at the conference. See Professor Horack's paper, The Role of Law in a Democracy, in the symposium, op. cit. supra note *. 
As to the great freedoms, notably freedom of speech, of religion, and of the press, however, I do not see the occasion for any fundamental change in our cherished ideals. Perhaps one can argue logically that these freedoms, too, should yield to the will of the majority. But we must compromise with our strict logical principles in order to preserve our ideals. I for one should have no hesitation in so doing, because, after all, the democratic way of life must be the subject of compromise and cannot be the essence of strict devotion to logical principle such as we may find, for example, in a dictator government. I doubt, however, if even compromise is called for. Because a democracy cannot function except that its process be kept clear and unclogged, we need to cherish these freedoms for the very life of democracy itself. The ideology which has firmly embedded these rights in an inflexible Constitution has strong arguments in its support. Unlike the various vague constitutional principles which a half century or more ago were erected into legislative policemen, these are clear and demanding in their expression. The very forcefulness of their statement in constitutional form leads us to recognize all the more how important they are; the experience of other countries shows how necessary they are for our preservation.

Since, therefore, I consider certain of these discussed changes more immediately necessary than others, I find myself not wholly convinced of the wisdom of another proposal recently considered, that of a constitutional convention. ${ }^{26}$ True, such a convention might be vastly worth while as a mere educative organ if the leading men of the country could gather together and in a spirit of give and take, without ideological and historical inhibitions, discuss the current needs of a democratic government and practical ways and means of achieving them. No finer course of instruction for the whole country could be conceived even if no constitutional reform actually resulted. But I fear the same consequence as has occurred too often in state constitutional conventions, where those with vested interests in the status quo have been able to unite against the scattered proponents of diverse and varying reform and have prevented all change. Such a convention unfortunately would start with the opposition of all sorts of patriotic organizations as well, who would have vague fears of a complete constitutional revolution. Though we may well ask, as does John Chamberlain in a recent magazine, "Who is the patriot- the zealot or the realist?" yet we dare not minimize the power of the zealot. I expect that almost of necessity we shall have to proceed only step by step. Even one of the steps here suggested will constitute a vast mountain to sur-

${ }^{26}$ This proposal was also made at the conference, note * supra. 
mount, and I fear only the exigencies of the war crisis or the breakdown of defense will bring people in general to see its grave need.

One must come back, after all, to the pressure of public opinion, which is a healthful and invigorating thing, for so often it has achieved results where the forms of law seem opposed. After all, we have achieved one great and necessary fundamental of the democratic way of life in that we do have discussion, which, though often prejudiced and all too ill-informed, yet is free and vigorous. Moreover, even though slowly, yet in due time and in broad ways and trends the weight of public opinion makes itself manifest. I do not think lawyers have done their full part in helping to stimulate it. I do think they have done more than their share in trying to forge chains which in reality are nonexistent. In spite of all this there has been movement; and notwithstanding the fears of many, notwithstanding what may well be mistakes at localized points, I am quite sure that the trend of law and jurisprudence has been healthy, sound, and most deserving of encouragement. We become impatient at the slow growth of opinion. Particularly in a crisis does the need for quicker action seem overwhelming. But there is nothing to do except await the slower development, while in the meantime we give such push to the movement as we can. Perhaps even conferences of students and scholars can properly have their important and stimulating share in forcing consideration of new and desirable developments in democratic government. 